\title{
Farmers' Perception on Environmental Degradation due to Indiscriminate use of Modern Practices: A Case Study from Madurai District, Tamil Nadu
}

\author{
M. UMANATH ${ }^{*}$, R. PARAMASIVAM and T. THANGA DURAI \\ Tamil Nadu Agricultural University, Coimbatore-003, Tamil Nadu, India. \\ http://dx.doi.org/10.12944/CWE.11.1.35
}

(Received: February 02, 2016; Accepted: March 17, 2016)

\begin{abstract}
In this study, we attempted to assess the awareness and perception of farmers on the environmental degradation due to modern input usage in paddy cultivation in Southern Tamil Nadu. The two-stage random sampling procedure was followed to select the sample farmers and 66 farmers were surveyed in Vadipatti Taluk located on Periyar-Vaigai irrigation system in Tamil Nadu. The paired comparison technique was used to measure the level of awareness on the environmental problems and Tobit regression function was employed to identify the determinants of environmental awareness level. The results of the study revealed that only 23 per cent of the farmers were highly aware about the environmental degradation created by the indiscriminate application of modern inputs. Reduction in soil fertility, population size of soil micro-organism and earth worms were the well-known negative effects in the study region. Experience, education and extension contact were the major factors determining the perception and awareness about environmental degradation.
\end{abstract}

Key words: Environment, Degradation, Sustainable agriculture, Paired comparison, Tobit regression.

\section{INTRODUCTION}

Environment is a matrix of various ecosystems existing in a web of delicate relationship. Nature always tries to maintain equilibrium among these ecosystems. However, different activities of human being have started affecting the quality of the environment. Environmental pollution is observable in the form of alteration of the physical, chemical and biological qualities of the natural resources such as water, air and land. Pollution is a significant feature of environmental concern apart from deforestation, natural calamities, famine, etc. Both production and consumption activities affect the natural ecosystem. Recently, agricultural production system has been modified with modern technologies. The Spread of such technologies in agricultural sector is popularly known as the Green revolution which includes the development of high-yielding varieties of cereal grains, expansion of irrigation infrastructure, modernization of management techniques and using hybridized seeds, synthetic fertilizers and pesticides. These technologies contribute not only to the increased agricultural production, but also to the different kinds of environmental problems such as non-point source pollution, erosion and soil fertility loss. A number of literature has discussed the environmental problems produced in the agricultural production system (Edwards, 1989; Biswas, 1994; NAAS, 2005; Singh, 2000; Pimentel, 1996; Kumar et al., 1999).

Sustainability of the agriculture is of global concern today. Farmers have adapted to the more modernized input based agro-technologies in farming practices to meet the growing demand of food and fibre products for the ever increasing population in India. The agricultural productivity has got more momentum with the modernized agro techniques, but these technologies have not been properly and 
judiciously adopted throughout the nation by taking the overall agro-environmental conditions. This is because of the low level of awareness amongst the farmers regarding the proper use of such modern techniques and its environmental effects. The study of awareness and attitudes amongst the farmers regarding the environmental problems and harmful effect of some modern techniques may prove as better inputs for sustainable agricultural development planning. Keeping these facts in view, the present study is an attempt to assess the environmental awareness and attitudes amongst the farmers; and to examine the major determinants of perception on environmental problems and sustainable agriculture.

\section{Data and methodology Study area and Sampling procedure}

Periyar-Vagai canal irrigation is one of the major irrigation system and water source for tank and canal command area in southern Tamil Nadu covering the districts such as Theni, Dingidul, Madurai, Sivagangai and Ramnad districts. This irrigation system covers around 140000 ha. Of which, Madurai district alone accounted around 60 per cent of the command area. Paddy was the major crop using the water released from the Periyar irrigation system and cultivated as a monocrop in the district. Besides, the district holds $1^{\text {st }}$ rank in per ha consumption of NPK in the state with per ha consumption of $340 \mathrm{~kg}$ and the district is identified as one of the highest consumer of pesticide with 0.60 lit / ha of liquid and $0.32 \mathrm{~kg} /$ ha of dust (Statistical abstract of Tamil Nadu, 2010-11). Mono-cropping with paddy and higher level intensification of chemical fertilizers and pesticides may degrade the soil, water and agro ecosystem.

In order to explore the level of awareness on environmental degradation through farm practices, we purposively selected 'Vadipatti Taluk' from the Madurai district as a study area. Vadipatti Taluk includes 77 villages with the geographical area of 36083 ha. Around 40 per cent of total geographical area was coming under agricultural purpose. Irrigation intensity was estimated at 89 per cent. Paddy, sugarcane, fruits and vegetables were considered as the major crops grown in the taluk. About 43 per cent of the total workers were depending on agriculture. Among them, more than 80 per cent were agricultural labour. According to 2011 census, average family size was 4 with 70 per cent literacy rate in study area (Source: Asst. Director of Statistics, Madurai).

Two stage random sampling was adopted to select sample respondents. On the first stage, out of 77 villages, six study villages were selected at random based on the paddy area by using a random number table. In the second stage, 11 farmers were selected from each villages randomly, which comprises a sample size of 66 farmers. Primary data regarding inputs usage and their impacts on the environment were collected from the each selected paddy growing farmers through pre tested interview schedule. Selected study area in the irrigation

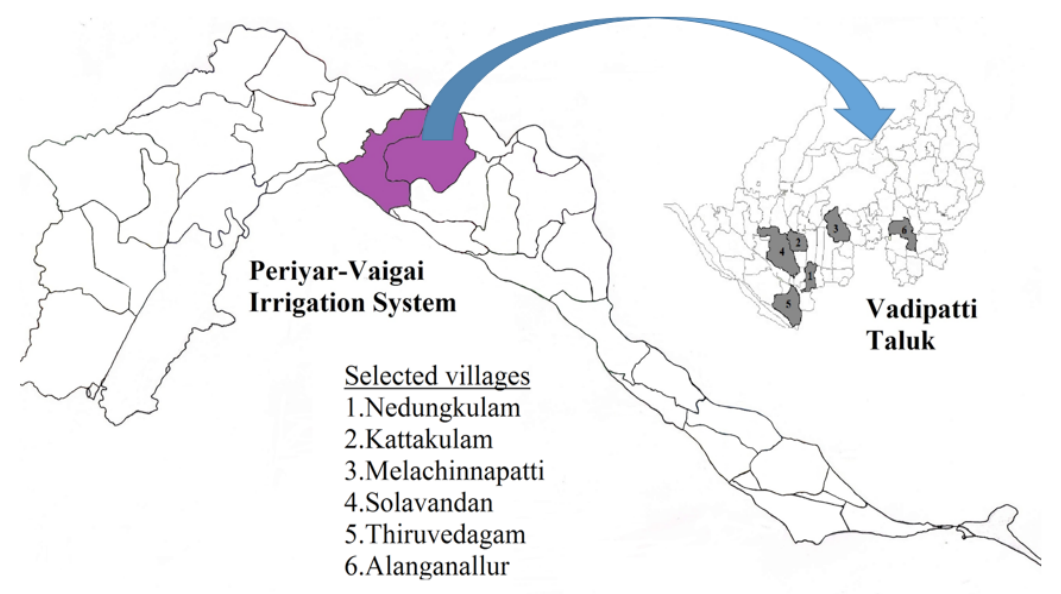

Fig. 1: Study area: Periyar - Vaigai Irrigation System and sample villages in Vadipatti taluk 
system and sample villages are presented in Figure 1.

\section{Tools of analysis}

In order to reveal the farmers' perception on the environmental impacts of technological change, we constructed an Environmental Awareness Index using the paired comparison scaling technique. Paired Comparison Analysis is a good way of weighing up the relative importance of different courses of action. This technique is useful where priorities are not clear, or are competing in importance. It provides a framework for comparing each course of action against all others, and helps to show the difference in importance between factors. In this study, a set of six specific environmental impacts, which seems important relative to each other, is read to the respondents. These six statements were derived after thorough review of literatures related to the inputs usage and environmental impacts in crop production
(Antle and Pingali, 1994; Berg, 2002; Kishi, 2002; Rahman, 2005; Nasurudeen and Mahesh, 2006; Isin and Yildirim, 2007; Rahman and Parkinson, 2007; Mariyono et al., 2010). Then, farmers were asked to reveal their opinion on these impacts. The statements given to the farmers to reveal the impacts are 1. Reduction of the soil fertility; 2 . Toxic effect on bird and fish population; 3 . Increased soil salinity; 4. Toxic effect on soil micro-organisms and earth worm populations; 5 . Toxic effect to consumers from fertilizer and pesticide residues; 6 . Increasing the pest and disease resistance due to intensive use of chemicals.

\section{Environmental Awareness Index (EAI)}

After obtaining the score value for each statement, the EAl was constructed by using the following formula;

$$
E A I=\sum_{j=0}^{6} \sum_{m=0}^{1} E_{j} R_{m}
$$

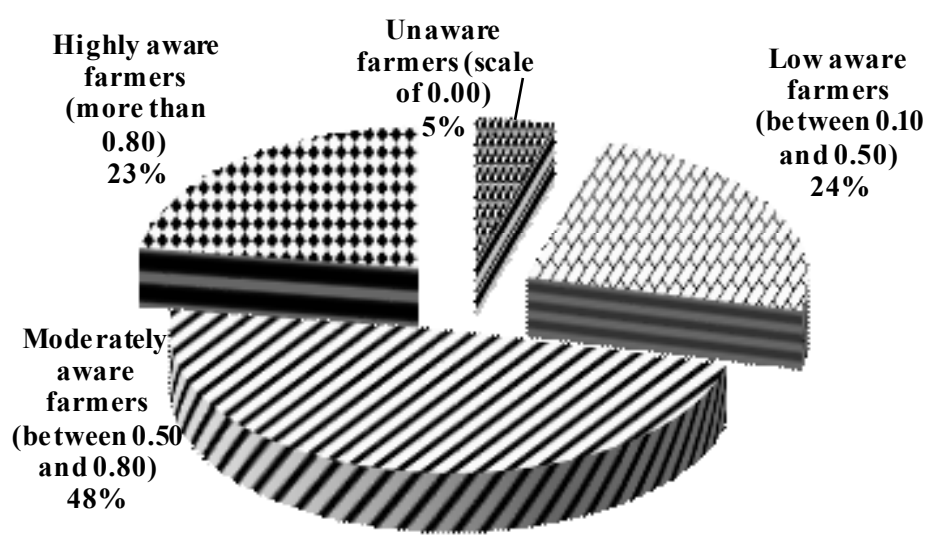

Fig. 2: Level of Awareness among farmers

Table 1: Ranking of farmers perception on environmental impacts of modern inputs usage in paddy cultivation

\begin{tabular}{llrc}
\hline No. & Statements & ScaleValues & MeanEAl \\
\hline A. & Reduction of the soil fertility & 1.000 & 0.864 \\
B. & Toxic effect on soil micro-organisms and earth worms population & 0.944 & 0.801 \\
C. & Increasing the pest and disease resistance. & 0.553 & 0.411 \\
D. & Increased soil salinity & 0.324 & 0.196 \\
E. & Toxic effect to consumers from fertilizer and pesticide residues & 0.166 & 0.080 \\
F. & Toxic effect on bird and fish population & 0.000 & 0.00 \\
& Absolute Average Discrepancy (AD) & 0.030 & $60.442(10.337)$ \\
& Chi - Square test & 6
\end{tabular}


where, $E_{i}$ is $j^{\text {th }}$ impact (statement) of over application of inputs revealed by the farmers, if there is an impact, the value is 1 otherwise $0 . R_{m}$ is the scale value of the $j^{\text {th }}$ impact (statement) given by the farmers' preference to avoid the problems, the weight 0 is assigned to lowest rank and 1 is assigned for highest rank.

\section{Tobit regression for estimating the determinants of EAl}

Since there are a number of farmers with zero environmental awareness index at the limit (censored data), Tobit regression analysis was used to estimate the determinants of environmental awareness. The stochastic model underlying Tobit may be expressed as follows:

$$
\begin{gathered}
E A l_{i}=b X_{i}+u \quad \text { if } b X_{i}+u>0=0 \\
\text { if } b X_{i}+u<=0, i=1,2, \ldots . n
\end{gathered}
$$

where, $\mathrm{n}$ is the number of farmers; $\mathrm{X}_{1}=$ Area cultivated; $X_{2}=$ Experience; $X_{3}=$ Education; $X_{4}$ $=$ Age $; X_{5}=$ Subsistence pressure ( proxy variable is Family Size); $X_{6}=$ Tenurial status; $X_{7}=$ Extension contact; $X_{8}=$ Income from source other than farming; $X_{9}=$ Irrigation facilities.

\section{RESULT AND DISCUSSION}

\section{Construction of scale value and EAI}

Among the set of six statements indicating the impact of inputs or resources use on the environment in the paddy production, 'Reduction of the soil fertility' featured at the top of the list of perceived adverse environmental impacts of modern agricultural technology diffusion, followed by 'toxic effect on soil micro-organism', 'increasing resistance to pest and diseases attack', 'increased soil salinity', 'increased pesticide residue on crop products' and 'toxic effect on bird and fish population'. For internal consistency check the absolute Average Discrepancy (AD) was calculated and it was found to be 0.03 . Since the absolute Average Discrepancy is quite small, it is inferred that the scale values obtained in this study are consistent (Table 1).

It seems that only five per cent of the farmers were completely unaware about the impact of modern input on environment. Around 48 per cent of farmers were moderately aware whereas 23 and 24 per cent were coming under highly aware and
Table 2: Determinants of Environmental Awareness Index (EAl)

\begin{tabular}{llcc}
\hline $\begin{array}{l}\text { S. } \begin{array}{l}\text { Independent } \\
\text { No Variables }\end{array} \\
\text { Estimates }\end{array}$ & $\begin{array}{c}\text { Tobit } \\
\mathbf{t} \text { - ratio }\end{array}$ \\
\hline 1 Constant & 0.255 & $1.62^{\mathrm{NS}}$ \\
2 & Area Cultivated & 0.0024 & $0.74^{\mathrm{NS}}$ \\
3 & Age & -0.0051 & $-1.76^{\star}$ \\
4 & Experience & 0.0076 & $2.63^{\star *}$ \\
5 & Education & 0.022 & $4.38^{\star \star *}$ \\
6 & Extension Contact & 0.151 & $2.45^{\star *}$ \\
7 & Subsistence Pressure & -0.011 & $-0.82^{\mathrm{NS}}$ \\
8 & Income from other sources & -0.128 & $-0.63^{\mathrm{NS}}$ \\
9 & Tenurial Status & -0.048 & $-0.95^{\mathrm{NS}}$ \\
10 & Irrigation Facilities & 0.026 & $0.34^{\mathrm{NS}}$ \\
\hline
\end{tabular}

Note: NS indicates non-significant; * and ${ }^{* *}$ indicate significance at five and one per cent level.

low aware category (Figure 2).

\section{Determinants of level of environmental awareness}

Among the socio-economic factors, experience, education and extension contacts play an important role in raising awareness. This clearly provides an opportunity to design and strategize information dissemination process through existing educational institutions and agricultural extension system. Whereas the level of environmental awareness among the farmers decreased as age of the farmers increases (Table 2).

\section{CONCLUSION}

To conclude, only 23 per cent of the farmers were high aware about the environmental impacts of using modern inputs in paddy production. Farmers were highly aware about the huge reduction in soil fertility and population of soil micro-organism and earth worms due to modern input usage. Experience, education and extension contact were the major determinants of higher level of awareness of negative impacts on ecosystem due to application of modern inputs of chemical fertilizers and pesticides. The results of the study may be helpful to the policy makers, farmers and other stakeholders who are working in the environmental degradation of agricultural ecosystem. 


\section{REFERENCES}

1. Antle, J. M. and Pingali, P. L. Pesticides, productivity, and farmer health: A Philippine case study. American J. of Agril. Econ, 76(3): 418-430 (1994).

2. Berg, H. Rice monoculture and integrated ricefish farming in the Mekong Delta, Vietnameconomic and ecological considerations. Eco. Econ, 41(1): 95-107 (2002).

3. Biswas, M.R. Agriculture and environment: a review, 1972-1992. Ambio, 23 (3): 192-197 (1994).

4. Edwards, C.A. "The importance of integration in sustainable agricultural systems". In: Paoletti, M.G., Stinner, B.R., Lorenzoni, G.G. (Eds.). Agricultural Ecology and Environment. Agric. Ecosyst. Environ. 27: 25-35 (1989).

5. Isin, S., and Yildirim, I. Fruit-growers perceptions on the harmful effects of pesticides and their reflection on practices: The case of Kemalpasa, Turkey. Crop Prot, 26(7): 917-922 (2007).

6. Kishi, M. Farmers Perceptions on Pesticides, and Resultant Health Problems from Exposures. Inter. $J$ of occu. and envir. health, 8(3): 175-181 (2002).

7. Kumar, P., Joshi, P.K., Johansen, C., and Ashokan, M. "Sustainability of Rice- Wheat Based Cropping System in India: SocioEconomic and Policy Issues", in Pingali P.L (Ed.) (1999), Sustaining Rice Wheat Production Systems: Socio-Economic and
Policy Isssues, Rice - Wheat Consortium Paper Series 5, New Delhi.

8. Mariyono, J., Kompas, T., and Grafton, R. Q. Shifting from Green Revolution to environmentally sound policies: technological change in Indonesian rice agriculture, $J$. of the Asia Pacific econ, 15(2): 128-147 (2010).

9. NAAS. "Policy Options for Efficient Nitrogen Use", Policy Paper No. 33, National Academy of Agricultural Sciences, New Delhi (2005).

10. Nasurudeen, P., and Mahesh, N. Socioeconomic and environmental perspectives of sustainable watershed eco-system in union territory of Pondicherry, Agri. Econ.Res. Rev, 19(conf): 49-58 (2006).

11. Pimentel, D. Green Revolution and Chemical Hazards. The Sci. of the Total Envir, 188 (Suppl. 1): S86-S98 (1996).

12. Rahman, S. Environmental impacts of technological change in Bangladesh agriculture:farmers'perceptions, determinants, and effects on resource allocation decisions, Agriecon, 33(1): 107-116 (2005).

13. Rahman, S., and Parkinson, R. J. Soil fertility and productivity relationships in rice production system, Bangladesh, Agri. syst, 92(1-3): 318-333 (2007).

14. Singh, R.B. Environmental Consequence of Agricultural Development: A Case Study From The Green Revolution State of Haryana, India. Agri, Ecosys and Envi, 82: 97-103 (2000). 